\title{
Soil carbon, multiple benefits
}

Eleanor Milne ${ }^{\mathrm{a}, \mathrm{b}, *}$, Steven A. Banwart ${ }^{\mathrm{c}}$, Elke Noellemeyer ${ }^{\mathrm{d}}$, David J. Abson ${ }^{\mathrm{e}}$, Cristiano Ballabio ${ }^{\mathrm{f}}$, Francesca Bampa ${ }^{\mathrm{f}}$, Andre Bationo $^{\mathrm{g}, 1}{ }^{\text {, Niels } H}$. Batjes ${ }^{\mathrm{h}}$, Martial Bernoux ${ }^{\mathrm{i}}$, Tapas Bhattacharyya ${ }^{\mathrm{j}}$, Helaina Black ${ }^{\mathrm{k}}$, Daniel E. Buschiazzo ${ }^{\text {, }}$ Zucong Cai ${ }^{\mathrm{m}}$, Carlos Eduardo Cerri ${ }^{\mathrm{n}}$, Kun Cheng ${ }^{\mathrm{o}}$, Claude Compagnone $^{\mathrm{p}}$, Rich Conant ${ }^{\mathrm{q}}$, Heitor L.C. Coutinho ${ }^{\mathrm{r}}$, Delphine de Brogniez ${ }^{\mathrm{f}}$, Fabiano de Carvalho Balieiro ${ }^{\mathrm{r}}$, Christopher Duffy ${ }^{\mathrm{s}}$, Christian Feller ${ }^{\mathrm{t}}$, Elaine C.C. Fidalgo ${ }^{\mathrm{r}}$, Cristiane Figueira da Silva ${ }^{\text {u }}$, Roger Funk v, Greta Gaudig w , Patrick T. Gicheru ${ }^{\mathrm{x}}$, Marty Goldhaber ${ }^{\mathrm{y}}$, Pia Gottschalk ${ }^{\mathrm{z}}$, Frederic Goulet $^{\text {aa }}$, Tessa Goverse ${ }^{\mathrm{ab}}$, Peter Grathwohl ${ }^{\mathrm{ac}}$, Hans Joosten $^{w}$, Peter T. Kamoni ${ }^{\mathrm{x}}$, Job Kihara ${ }^{\text {ad, }}$ Rene Krawczynski ${ }^{\text {ae }}$, Newton La Scala Jr. ${ }^{\text {af }}$, Philippe Lemanceau ${ }^{\text {ag }}$, Lianqing $\mathrm{Li}^{\circ}$, Zichuan $\mathrm{Li}^{\circ}$, Emanuele Lugato ${ }^{f}$, Pierre-Alain Maron ${ }^{\text {ag }}$, Christopher Martius ${ }^{\text {ah }}$, Jerry Melillo ai, Luca Montanarella ${ }^{\mathrm{f}}$, Nikolaos Nikolaidis ${ }^{\text {aj }}$, Generose Nziguheba ${ }^{\text {ak }}$, Genxing Pan ${ }^{\circ}$, Unai Pascual $^{\text {al,am,an }}$, Keith Paustian ${ }^{\text {ao }}$, Gervasio Piñeiro ${ }^{\text {ap }}$, David Powlson ${ }^{\text {aq }}$, Alberto Quiroga ${ }^{\mathrm{d}}$, Dan Richter ${ }^{\text {ar }}$, Annie Sigwalt ${ }^{\text {as }}$, Johan Six ${ }^{\text {at }}$, Jo Smith ${ }^{\text {au }}$, Pete Smith ${ }^{\text {au, }}$, Michael Stocking $^{\text {av }}$, Franziska Tanneberger ${ }^{\text {w }}$, Mette Termansen $^{\text {aw }}$, Meine van Noordwijk ${ }^{\text {ax }}$, Bas van Wesemael ${ }^{\text {ay }}$, Rodrigo Vargas ${ }^{\mathrm{az}}$, Reynaldo Luiz Victoria $^{\text {ba }}$, Boaz Waswa ${ }^{\text {ad }}$, David Werner ${ }^{\text {bb }}$, Sabine Wichmann ${ }^{\text {w }}$, Wendelin Wichtmann ${ }^{\mathrm{bc}}$, Xuhui Zhang ${ }^{\mathrm{bd}}$, Yongcun Zhao be, Jinwei Zheng ${ }^{\circ}$, Jufeng Zheng ${ }^{\circ}$

${ }^{a}$ Colorado State University, USA

${ }^{\mathrm{b}}$ University of Leicester, UK

${ }^{\mathrm{c}}$ Kroto Research Institute, The University of Sheffield, UK

d Facultad de Agronomía, Universidad Nacional de La Pampa, Argentina

${ }^{\mathrm{e}}$ FuturES Research Center, Leuphana Universität, Germany

${ }^{\mathrm{f}}$ European Commission Directorate General Joint Research Centre, Italy 
${ }^{\mathrm{g}}$ Alliance for Green Revolution in Africa (AGRA), Kenya

${ }^{\mathrm{h}}$ ISRIC - World Soil Information, The Netherlands

${ }^{\mathrm{i}}$ French Research Institute for Development (IRD), France

${ }^{\mathrm{j}}$ National Bureau of Soil Survey and Land Use Planning (Indian Council of Agricultural Research), India

${ }^{\mathrm{k}}$ The James Hutton Institute, UK

${ }^{1}$ National Institute for Agronomic Research of Argentina (INTA), National University of La Pampa, Argentina

${ }^{\mathrm{m}}$ School of Geography Science, Nanjing Normal University, China

${ }^{\mathrm{n}}$ Department of Soil Science, University of São Paulo (USP), Brazil

${ }^{\circ}$ Institute of Resource, Ecosystem and Environment of Agriculture, Nanjing Agricultural University, China

${ }^{\mathrm{p}}$ AgroSup, Dijon - INRA, France

${ }^{\mathrm{q}}$ Natural Resource Ecology Laboratory and Department of Ecosystem Science and Sustainability, Colorado State University, USA

${ }^{\mathrm{r}}$ National Centre for Soil Research (Embrapa Soils), Brazil

${ }^{\mathrm{s}}$ National Science Foundation (NSF) Critical Zone Observatory, Pennsylvania State University, USA

${ }^{\mathrm{t}}$ French Research Institute for Development (IRD), France

u Rural Federal University of Rio de Janeiro (UFRRJ), Brazil

${ }^{\mathrm{v}}$ Institute for Soil Landscape Research, Leibniz Centre for Agricultural Landscape Research (ZALF), Germany

${ }^{\mathrm{w}}$ Institute of Botany and Landscape Ecology, Ernst Moritz Arndt University of Greifswald, Germany

${ }^{x}$ Kenya Agricultural and Livestock Research Organization (KALRO), Kenya

${ }^{y}$ US Geological Survey, USA

${ }^{\mathrm{z}}$ Potsdam Institute for Climate Impact Research, Germany

aa CIRAD Agricultural Research for Development, France

${ }^{\mathrm{ab}}$ Division of Early Warning and Assessment, United Nations Environment Programme (UNEP), Kenya

${ }^{\text {ac }}$ Center for Applied Geosciences, Tuebingen University, Germany

${ }^{\text {ad }}$ International Center for Tropical Agriculture (CIAT), Kenya

ae Brandenburg University of Technology, Germany

af Universidade Estadual Paulista (Unesp), Brazil

ag INRA - University of Burgundy Joint Research Unit for Soil Microbiology and the Environment, France

ah Center for International Forestry Research (CIFOR), Indonesia

ai The Ecosystems Center, Marine Biological Laboratory, USA

aj Department of Environmental Engineering, Technical University of Crete, Greece

${ }^{\mathrm{ak}}$ International Institute of Tropical Agriculture, Nairobi, Kenya

al Ikerbasque, Basque Foundation for Science, Spain

am Basque Centre for Climate Change, Spain

an University of Cambridge, Department Land Economy, Cambridge, UK

ao Department of Soil and Crop Sciences, Natural Resource Ecology Laboratory, Colorado State University, USA

ap Department of Natural Resources, University of Buenos Aires, Argentina

${ }^{\text {aq }}$ Department of Sustainable Soils and Grassland Systems, Rothamsted Research, UK

${ }^{a r}$ Division of Environmental Sciences and Policy, Duke University, USA

as Département Economie et Sciences Sociales, Groupe ESA, France

at Sustainable Agroecosystem Group, Swiss Federal Institute of Technology, ETH-Zurich, Zurich, Switzerland

${ }^{\mathrm{au}}$ Institute of Biological and Environmental Sciences, School of Biological Sciences, University of Aberdeen, UK

${ }^{\text {av }}$ School of International Development, University of East Anglia, UK

${ }^{\text {aw }}$ Department of Environmental Science, Aarhus University, Denmark

${ }^{a x}$ ICRAF (World Agroforestry Centre), Indonesia

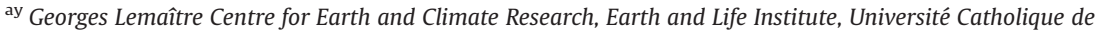
Louvain, Belgium

${ }^{\text {az }}$ Plant and Soil Sciences, University of Delaware, USA

ba Universidade de São Paulo, Brazil

${ }^{\mathrm{bb}}$ School of Civil Engineering and Geosciences, Newcastle University, UK

bc Michael Succow Foundation for the Protection of Nature, Ernst Moritz Arndt University of Greifswald, Germany

${ }^{\text {bd }}$ College of Resources and Environmental Sciences, Nanjing Agricultural University, China

be Institute of Soil Science, Chinese Academy of Sciences, China

\footnotetext{
* Corresponding author at: Colorado State University, USA.

E-mail addresses: eleanor.milne@colostate.edu (E. Milne), s.a.banwart@sheffield.ac.uk (S.A. Banwart), noellemeyer@agro.unlpam.edu.ar, enoellemeyer@gmail.com, aquiroga@anguil.inta.gov.ar (E. Noellemeyer), abson@leuphana.de (D.J. Abson), cristiano.ballabio@jrc.ec.europa.eu (C. Ballabio), francesca.bampa@gmail.com (F. Bampa), abationo@outlook.com (A. Bationo), niels.batjes@wur.nl (N.H. Batjes), martial.bernoux@ird.fr (M. Bernoux), tapas11156@yahoo.com (T. Bhattacharyya), helaina.black@hutton.ac.uk (H. Black), buschiazzo@agro.unlpam.edu.ar, debuschiazzo@yahoo.com (D.E. Buschiazzo), zccai@njnu.edu.cn (Z. Cai), cepcerri@usp.br (C.E. Cerri),

kuncheng@aliyun.com (K. Cheng), c.compagnone@agrosupdijon.fr (C. Compagnone), conant@nrel.colostate.edu (R. Conant), heitor.coutinho@embrapa.br (H.L.C. Coutinho), delphine.debrogniez@gmail.com (D. de Brogniez),
} 


\section{A R T I C L E I N F O}

Article history:

Received 25 November 2014

Accepted 27 November 2014

\begin{abstract}
A B S T R A C T
In March 2013, 40 leading experts from across the world gathered at a workshop, hosted by the European Commission, Directorate General Joint Research Centre, Italy, to discuss the multiple benefits of soil carbon as part of a Rapid Assessment Process (RAP) project commissioned by Scientific Committee on Problems of the Environment (SCOPE). This collaboration led to the publication of the SCOPE Series Volume 71 "Soil Carbon: Science, Management and Policy for Multiple Benefits"; which brings together the essential scientific evidence and policy opportunities regarding the global importance of soil carbon. This short communication summarises the key messages of the assessment including research and policy implications.
\end{abstract}

(c) 2014 Elsevier Ltd. All rights reserved.

\section{Introduction}

The health of the Earth's soils is fundamental to the survival of humanity, yet soils are under pressure from the increasing demands of a growing population. By the year 2050, the Earth's soils will be required to provide the following services for an estimated 9.6 billion people:

- Supporting services: The cycling of nutrients, the retention and release of water, the formation of soil, provision of habitat for biodiversity, the exchange of gases with the atmosphere and the degradation of plant and other complex materials.

- Regulating services: Regulate climate through the sequestration of carbon from the atmosphere and control of greenhouse gas emissions, regulate water flow and the filtration and purification of water, regulate air quality by attenuation of pollutants from wind erosion, atmospheric deposition and land contamination.

- Provisioning services: Sustain food, fuel and fibre production, water availability, non-renewable mineral resources and a platform for construction.

\footnotetext{
(footnote continued)

fabiano.balieiro@embrapa.br (F.d.C. Balieiro), cxd11@psu.edu (C. Duffy), christian.feller@ird.fr (C. Feller), elaine.fidalgo@embrapa.br (E.C.C. Fidalgo), cfigueirasilva@yahoo.com.br (C.F. da Silva), rfunk@zalf.de (R. Funk), gaudig@uni-greifswald.de (G. Gaudig), patrick.gicheru@kalro.org (P.T. Gicheru), mgold@usgs.gov (M. Goldhaber), pia.gottschalk@pik-potsdam.de (P. Gottschalk), frederic.goulet@cirad.fr (F. Goulet), tessa.goverse@unep.org (T. Goverse), grathwohl@uni-tuebingen.de (P. Grathwohl), joosten@uni-greifswald.de (H. Joosten), pkamoni@gmail.com (P.T. Kamoni), j.kihara@cgiar.org (J. Kihara), rene.krawczynski@tu-cottbus.de (R. Krawczynski), lascala@fcav.unesp.br (N. La Scala Jr.), philippe.lemanceau@dijon.inra.fr (P. Lemanceau), lqli@njau.edu.cn (L. Li), lizichuan2004@163.com (Z. Li), emanuele.lugato@jrc.ec.europa.eu (E. Lugato), pierre-alain.maron@dijon.inra.fr (P.-A. Maron), c.martius@cgiar.org (C. Martius), jmelillo@mbl.edu (J. Melillo), luca.montanarella@jrc.ec.europa.eu (L. Montanarella), nikolaos.nikolaidis@enveng.tuc.gr (N. Nikolaidis), g.nziguheba@cgiar.org (G. Nziguheba), pangenxing@aliyun.com (G. Pan), unai.pascual@bc3research.org (U. Pascual), keith.paustian@colostate.edu (K. Paustian), pineiro@ifeva.edu.ar (G. Piñeiro), david.powlson@rothamsted.ac.uk (D. Powlson), aquiroga@anguil.inta.gov.ar (A. Quiroga), drichter@duke.edu (D. Richter), a.sigwalt@groupe-esa.com (A. Sigwalt), jsix@ethz.ch (J. Six), jo.smith@abdn.ac.uk (J. Smith), pete.smith@abdn.ac.uk (P. Smith), m.stocking@uea.ac.uk (M. Stocking), tanne@uni-greifswald.de (F. Tanneberger), mter@dmu.dk (M. Termansen), m.vannoordwijk@cgiar.org (M. van Noordwijk), bas.vanwesemael@uclouvain.be (B. van Wesemael), rvargas@udel.edu (R. Vargas), reynaldo.victoria@gmail.com (R.L. Victoria),b.waswa@cgiar.com (B. Waswa), david.werner@ncl.ac.uk (D. Werner),wichmann@uni-greifswald.de (S. Wichmann), wendelin.wichtmann@succow-stiftung.de (W. Wichtmann), xuhuizhang@njau.edu.cn (X. Zhang), yczhao@issas.ac.cn (Y. Zhao), zhengjw@njau.edu.cn (J. Zheng), zhengjufeng@njau.edu.cn (J. Zheng).

${ }^{1}$ Present address: Action for Integrated Rural Development, Accra, Ghana.
} 
- Cultural services: The preservation of archaeological remains; outdoor recreational pursuits; ethical, spiritual and religious interests; the identity of landscapes and supporting habitat.

The organic matter content of soils and more specifically soil organic carbon (SOC) is critical to the majority of these services. However, in the past 25 years an estimated quarter of the Earth's land has suffered degradation as a result of SOC loss. Therefore, we are currently operating at suboptimal SOC levels far below those required for a "sustainable livelihood". Restoring, increasing and protecting soil organic carbon (SOC) should therefore be a global priority.

In March 2013, 40 leading experts from across the world gathered at a workshop, hosted by the European Commission, Directorate General Joint Research Centre, Italy, to discuss these issues as part of a Rapid Assessment Process (RAP) project commissioned by Scientific Committee on Problems of the Environment (SCOPE). This collaboration led to the publication of the SCOPE Series Volume 71 "Soil Carbon: Science, Management and Policy for Multiple Benefits" (Banwart et al., 2014); which brings together the essential scientific evidence and policy opportunities regarding the global importance of soil carbon. The book is a timely contribution that supports the 5 pillars of the Global Soil Partnership (http://www.fao.org/globalsoilpartnership/en/) and the related activities of the 2015 International Year of Soils (http://www.fao.org/soils-2015/en/). Here we present some of the key messages to come out of the project.

\section{Soil carbon, multiple benefits}

Maintaining and increasing soil carbon content yields substantial, multiple benefits. Greater soil carbon helps to maintain soil structure by forming stable, larger aggregates that hold plant-available water in intra-aggregate pores and larger inter-aggregate pores that create greater soil permeability, aeration and drainage. Increasing soil carbon provides substrate and energy to support microbial activity, provides a reservoir of organic N, P and other nutrients for plant productivity, and creates more physically cohesive soil to resist soil losses by wind or water erosion and by protecting occluded organic matter within the larger aggregates. Increases in carbon storage in soils function to mitigate climate change.

\section{A global research programme}

Under given climatic, substrate, relief and hydrological conditions, there are biophysical limits to how much carbon a soil can store. However, for many soils there is little information on their inherent capacity to sequester carbon as native reference soils no longer exist. In contrast, economic, social and other drivers can rapidly change land use (e.g., forest to grassland) and management (low input to high input agriculture) with potentially major consequences for the soil carbon balance. A targeted applied research plan, accompanied by management actions is needed to determine the impacts of different land use and management practices on SOC in site-specific conditions at different spatial and temporal scales. Therefore, there is a need to create a global research programme to reduce the uncertainty associated with SOC management across terrestrial ecosystems.

\section{Preventing SOC loss}

An urgent priority is to stop losses of SOC in terrestrial ecosystems, especially in ecological hotspots and carbon-rich soils. Priority areas include the world's peatlands that cover only $3 \%$ of the global land surface but store an estimated $500 \mathrm{Gt}$ of carbon (Joosten and Couwenberg, 2008), and the world's drylands that have a low SOC stock per unit area, but cover an estimated $41 \%$ of the Earth's land surface and are subject to the highest levels of degradation. Loss of SOC in these areas results from land use change (grassland conversion to annual or perennial cropland) and intensification of 
land use in areas where conversion has already taken place. Intensification raises the prospect of greater physical disturbance of soils, e.g. tilling of grasslands. More intense tillage and greater areas of mechanical tillage are expected to coincide with greater loss of soil carbon due to greater exposure of soil carbon to $\mathrm{O}_{2}$ (Powlson et al., 2011).

In addition, predicted changes to regional as well as global climate in the coming decades will impact soil carbon (Schils et al., 2008; Conant et al., 2011). Drier, warmer conditions are expected to coincide with higher rates of soil carbon mineralisation and the associated loss of soil functions. Warming of permafrost soils will expose accumulated carbon in cold regions to much greater rates of microbial decomposition (Schuur and Abbot, 2011).

\section{Promoting SOC enhancement}

Agricultural lands created from drained peatlands have the potential for carbon sequestration under the appropriate management, for example rewetting and use for flooded crops or return to native vegetation. Degraded agricultural lands in semi-arid climates that originally were grasslands, savannahs or tropical dry forests also have large global potential for enhancement of SOC, due to the extended area they cover. Taking as an example the semi-arid agricultural lands of North America, the soil organic carbon content diminished by on average 50\% during the period of arable agricultural expansion. Similar consideration is valid for arid land in China, Mongolia, Russia, Africa and South America

Organic matter plays a catalysing role for the maintenance of soil structure, nutrient turnover and other soil functions. The fundamental strategy of restoring soil functions is based on agro-ecological land care practices that entail carbon additions. These additions can be either through aboveground vegetation or roots, or through inputs from agricultural, urban and industrial organic waste. Typically, soil ecosystems are restored naturally unless they have passed a tipping point. However, the natural restoration process can take decades (Zach et al., 2006) or centuries (Nikolaidis, 2011). Reversing the degradation trend and enhancing soil ecosystem services requires significantly higher additions of organic matter and in most cases the process of restoration will not achieve the original level of carbon stocks (Zach et al., 2006).

\section{From potential to implementation}

We have substantial knowledge of the technical measures needed to increase SOC in most land use systems. However, in many cases this knowledge is not being put into practice. A key reason could be the mismatch between private and social benefits and the costs of SOC management across temporal and spatial scales. Most actions needed at the local scale are complementary at the national and global scales and can be aggregated. If all single farms are prosperous, the catchment and the nation are also prosperous and vice versa. However, some soil ecosystem functions only become meaningful at a larger scale such as climate change mitigation by avoiding SOC losses, reducing GHG emissions and sequestering SOC. Such goals can only be achieved when implemented at many farms simultaneously as a single farm has a negligible effect on the global level, where "climate" operates. In addition, incentives to change action at the local level need to be provided for benefits that may be more apparent at the global level.

Interestingly, the current best practices (both biophysical and socioeconomic) that are applied by the different actors occur at the lower scales and these are mostly related to biophysical/technological innovations. Fewer best practices are found as we move up along in the spatial scale. However, innovations are particularly needed to bridge the current incompatibilities between short- and longterm objectives. Apart from technological innovations there is a strong need for social and political advances. Political advances are mainly related to new types of governance structures in the public and private sectors so that policies at higher spatial levels, in governments or companies, filter down towards the lower scales and ultimately reach the consumers and the farmers who can effectively bring about SOC sequestration. 


\section{A strategy for taking soil carbon into the policy arena}

It is imperative that issues involving SOC achieve a higher policy profile. The multiple benefits derived from SOC interact at scales beyond the individual farm, and therefore should be addressed and remunerated through public incentives at scales ranging from the catchment to the nation. SOC is often privately managed but has impacts on atmospheric $\mathrm{C}$ that are unambiguously global. Aggregations of local soil C management can either worsen or mitigate climate change. Land management that is locally profitable, in the short term, could conceivably cause long term soil degradation that is bad for long term global food security. This planetary dimension requires a collective management approach with governance arrangements that are targeted at different stakeholders at different levels. Governance structures must embed SOC in all levels of decisionmaking and action. The principal actors involved are land users as the immediate guardians of SOC, local professionals, local government and NGOs. Good governance by nation states has a pivotal role both in filtering down to the local level, but also aggregating up to the global and international levels.

SOC is now recognised as a global environmental issue and policies should capitalise on UN institutions that promote SOC sequestration. At present, most UN agencies are promoting convergent strategies, e.g. the climate-smart agriculture initiative, and the Global Donors Platforms for Rural Development (GPDRP, 2014).

\section{Conclusion}

A new focus on soil carbon at all levels of governance for soil management would better enable the full potential of soil ecosystem services to be realised. This advance is urgent and essential. There is significant opportunity through soil carbon management to help meet the demand for food, fuel, and clean water worldwide. It is also an essential step towards soil management that establishes enhanced soil functions that last - in order to meet the needs of future generations.

\section{References}

Soil Carbon - Science, Management and Policy for Multiple Benefits. In: Banwart, S.A., Noellemeyer, E., Milne, E. (Eds.), Scientific Committee on Problems of the Environment (SCOPE) Series. CABI, Wallingford, UK. (Volume 71, 31 Chapters, ISBN: 9781780645322).

Conant, R.T., Ryan, M.G., Agren, G.I., Birge, H.E., Davidson, E.A., Eliasson, P.E., Evans, S.E., Frey, S.D., Giardina, C.P., Hopkins, F.M., Hyvonen, R., Kirschbaum, M.U.F., Lavallee, J.M., Leifeld, J., Parton, W.J., Megan Steinweg, J., Wallenstein, M.D., Wetterstedt, J. A.M., Bradford, M.A., 2011. Temperature and soil organic matter decomposition rates synthesis of current knowledge and a way forward. Glob. Change Biol. 17, 3392-3404.

GPDRP, 2014. Global Donors Platforms for Rural Development. 〈www.donorplatform.org〉.

Joosten, H., Couwenberg, J., 2008. Peatlands and carbon. In: Parish, F., Sirin, A., Charman, D., Joosten, H., Minaeva, T., Silvius, M. (Eds.), Assessment on Peatlands, Biodiversity and Climate Change. Global Environment Centre and Wageningen: Wetlands International, Kuala Lumpur, pp. 99-117.

Nikolaidis, N.P., 2011. Human impacts on soil: tipping points and knowledge gaps. Appl. Geochem. 26, $230-233$.

Powlson, D.S., Whitmore, A.P., Goulding, K.W.T., 2011. Soil carbon sequestration to mitigate climate change: a critical reexamination to identify the true and the false. Eur. J. Soil Sci. 62, 42-55.

Schils, R., Kuikman, P., Liski, J., Van Oijen, M., Smith, P., Webb, J., Alm, J., Somogyi, Z., Van den Akker, J., Billett, M., Emmett, B., Evans, C., Lindner, M., Palosuo, T., Bellamy, P., Jandl, R., Hiederer, R., 2008. Review of existing information on the interrelations between soil and climate change (ClimSoil). Final report. European Commission, Brussels.

Schuur, E.A.G., Abbot, B., 2011. High risk of permafrost thaw. Nature 480, 32-33.

Zach, A., Tiessen, H., Noellemeyer, E., 2006. Carbon turnover and carbon-13 natural abundance under land use change in semiarid Savanna soils of La Pampa, Argentina. Soil Sci. Soc. Am. J. 70, 1541. 